\title{
B.М. Монастирський
}

Кафедра хірургії факультету післядипломної освіти (зав. - проф. А.І. Суходоля) Віннищького нащіонального медичного університету імені М.І. Пирогова

\section{ПОКАЗНИКИ КЛІТИННОГО ЦИКЛУ КЛІТИН КІРКОВОЇ РЕЧОВИНИ СДИНОЇ НИРКИ ПІСЛЯ КОНТРЛАТЕРАЛЬНОӤ НЕФРЕКТОМЇ̈}

\begin{abstract}
Резюме. В експерименті на щурах за допомогою метода проточної ДНК-цитометрії вивчено динаміку показників клітинного циклу та фрагментації ДНК клітин кіркової речовини єдиної нирки, що залишилася після нефректомії у щурів. Встановлено підвищення активності проліферації та оновлення в найближчому післяопераційному періоді після нефректомії, що пояснює зростання маси та об'єму нирки. Гіпертрофія єдиної нирки щурів після однобічної нефректомії супроводжується активацією апоптозу в тканині нирки, що виявляється у збільшенні ДНК-фрагментації в нирковій тканині єдиної нирки експериментальних тварин. Пік цієї активації спостерігався на 7 добу після нефректомії. Це вказує на активацію апоптозу в умовах посиленої проліферації.
\end{abstract}

Ключові слова: єдина нирка, клітинний цикл, ДНК-цитометрія.

Питання компенсації структури та функції при втраті одного з парних органів мають інтерес для клінічної практики, в зв'язку з чим зростає увага дослідників до експериментального вивчення органів, які залишилися після видалення контрлатеральних, у тому числі нирки, що залишилася після однобічної нефректомії [1]. Пацієнти, яким проведена резекція нирки, страждають від погіршення функції нирок залежно від обсягу ниркової втрати паренхіми. Деякі дослідники пропонують переглянути гіпотезу про гіперфункцію контрлатеральної нирки, оскільки вона не $є$ клінічно та статистично значущою [2].

Нирка не має готового резерву тканини на випадок втрати контрлатерального органа. Компенсаторна вікарна гіпертрофія іiі розвивається тільки після втрати контрлатеральної. У науковій літературі йде дискусія про механізми та закономірності розвитку компенсаторних процесів при оперативному видаленні однієї нирки [3]. Раніше вважалося, що нирка, після того як вона сформувалася і виросла, не регенерує й є статичним органом, а заміна відмерлих клітин відбувається тільки за рахунок збільшення інших клітин у розмірах $[4,5]$. Як вчені з'ясували тепер, до поділу здатні не тільки стовбурові клітини нирок, а й звичайні клітини епітелію інших ниркових тканин [6]. Нирка відновлюється впродовж усього життя людини.

На думку багатьох авторів, які займаються цією проблемою, інтактний орган, який залиши- вся після видалення контрлатеральної нирки, відновлює обсяг функціонуючих структур за рахунок їх гіпертрофії [7, 8], гіперплазії клітин [9], збільшення мітотичної активності [10], компенсаторного збільшення функціонального навантаження на решту клітин. Ряд авторів відзначає, що всі відділи нефрона беруть участь у реалізації відновних процесів [11]. Разом з тим, при експериментальній стимуляції вступу подоцитів у мітоз встановлено, що дані клітини не можуть ефективно завершити цитокинез, внаслідок чого утворюються анеуплоїдні подоцити, які, як правило, гинуть. Тому відновлення ниркових клубочків відбувається за рахунок гіпертрофії подоцитів [12].

Враховуючи існування лише поодиноких досліджень, присвячених визначенню методом ДНКцитометрії показників клітинного циклу клітин кіркового шару єдиної нирки, особливо актуальним $€$ встановлення показників змін проліферативних процесів у нирці, яка залишилася після однобічної нефректомії, що й обумовило дане дослідження.

Мета дослідження: дослідити за допомогою методу проточної ДНК-цитометрії динаміку показників клітинного циклу та фрагментації ДНК клітин кіркової речовини єдиної нирки, що залишилася після нефректомії у щурів.

Матеріал іметоди. Тварин розподілили на дві групи: інтактні тварини, яким не проводили ніяких втручань (12 статевозрілих шурів); дослідні тварини, яким виконували оперативне втручання

(C) Монастирський В.М., 2016 
- нефректомію лівої нирки. Експериментальне дослідження динаміки показників клітинного ичиклу та фрагментаиії ДНК єдиної нирки, щьо залишилася після контрлатеральної нефректомії (через 7, 14. 21, 30, 60 та 90 діб) виконано на $60 \mathrm{cma-}$ тевозрілих щурах-самиях масою 155-220 г на базі науково-дослідного иентру (НДЦ) Вінницького начіонального медичного університету імені М.I. Пирогова. Утримання та маніпуляиії з тваринами проводили у відповідності до "Загальних етичних принщипів експериментів на тваринах", ухвалених Першим національним конгресом з біоетики (Київ, 2001), також керувалися рекомендаціями "Свропейської конвениії про захист хребетних тварин, які використовуються для експериментальних та інших наукових иілей” (Страсбург, 1985) і положеннями "Правил доклінічноі оцінки безпеки фармакологічних засобів (GLP)”.

Вміст ДНК в ядрах клітин кіркової речовини нирок шурів визначався методом проточної ииитометрії [13]. Суспензї̈ ядер з клітин нирки були отримані за допомогою спеціального розчину для дослідження ядерної ДНК CyStain DNA Step 1 piрми Partec, Німеччина, який дозволяє швидко та одночасно виконувати екстракиію ядер і маркувати ядерну ДНК діамідинофеніліндолом (DAPI), який входить до його складу. У процесі виготовлення нуклеарних суспензій використовувались спеціальні одноразові фільтри CellTrics 50 мкм (Partec, Німеччина).

Проточний аналіз виконувався на багатофункиіональному науково-дослідному проточному иитометрі "Рагtес PAS" фірми Рагtес, Німеччина (рис. 1).

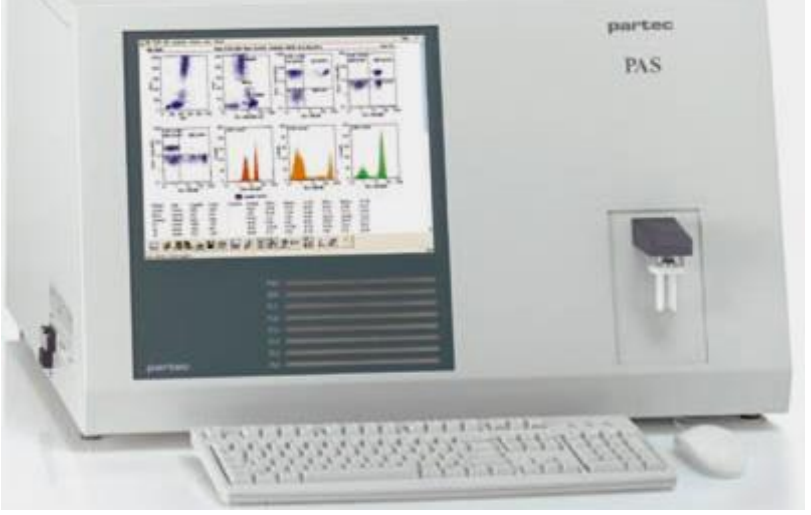

Рис. 1. Лазерний проточний циитофлюориметр PARTEC “РAS”, Німеччина

Для збудження флуоресиениії DAPI застосовувалось УФ-випромінювання. 3 кожного зразка нуклеарної суспензії аналізу підлягало 20 тис. подій. Розподіл ДНК, яка відображує клітинний ичикл та фрагментачію ДНК, показані на сторіниі з однією гістограмою з використанням лінійної шкали. Циклічний аналіз клітин виконаний засобами програмного забезпечення FloMax (Partec, Німеччина) у повній ичифровій відповідності згідно математичної моделі. Цифровий результат показаний у вікні ииклічного аналізу клітин за алгоритмом клітинного ииклу разом з графічною демонстрацією фаз G0G1, S, G2+M та експериментальними даними.

Статистична обробка отриманих результатів була проведена в пакеті "STATISTICA 6.1" (належить НДЦ ВНМУ імені M.I. Пирогова, лічензійний № ВXXR901E246022FA) із застосуванням непараметричних методів оцінки отриманих результатів. Оцінювали правильність розподілу ознак за кожним із отриманих варіаційних рядів, середні значення кожної ознаки, щу вивчалася, та стандартне квадратичне відхилення. Достовірність різниці значень між незалежними кількісними величинами визначали за допомогою $U$-критерія Мана-Уітні.

Результати дослідження та їх обговорення. За порівнянням показників клітинного циклу клітин кіркової речовини правих нирок статевозрілих щурів через 7 діб після нефректомії лівої нирки $з$ показниками, отриманими в інтактних тварин, були виявлені суттєві зміни клітинного циклу клітин кіркової речовини нирки (рис. 2). Так, збільшилась частка клітин, які перебували у фазі синтезу ДНК - фазі $\mathrm{S}(\mathrm{p}<0,05)$. Збільшення частки клітин у фазі S відбувалось за рахунок зменшення частки клітин у фазах G0/G1 (рис. 3). Разом з тим, у даному терміні спостерігалось статистично значуще збільшення в 1,26 раза кількості клітин 3 фрагментованою ДНК (інтервал SUB-G0G1), тобто $з$ ознакою апоптозу. Відбувається збільшення частки клітин у постсинтетичній премітотичній фазі G2 та фазі мітозу М (G2+M). У фазі G2 клітина здійснює контроль за точністю редуплікації ДНК і виправляє виявлені збої. Частка інтервалу $\mathrm{S}+\mathrm{G} 2+\mathrm{M}$, що характеризує активно проліферуючу частину клітинного субстрату та забезпечує постійне оновлення, теж зросла на 7-му добу. Індекс проліферації становить 17,31土 1,09\% (таблиця).

Характеризуючи синтетичний період клітинного циклу, коли відбувається синтез ДНК і редуплікація хромосом, внаслідок чого вміст ДНК в ядрі подвоюється, зафіксовано, що протягом 60 діб спостереження за нефректомованими тваринами частка клітин кіркової речовини нирки, якаперебувала у фазі S, була більшою порівняно з інтактними тваринами. Разом 3 тим, слід відмі 
Таблиия

Показники клітинного циклу та фрагментації ДНК клітин кіркової речовини сдиної нирки

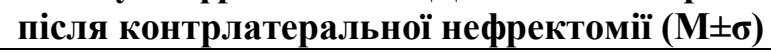

\begin{tabular}{|c|c|c|c|c|c|c|c|}
\hline \multirow{2}{*}{ 离 } & \multirow{2}{*}{$\begin{array}{l}\text { Групи } \\
\text { тварин }\end{array}$} & \multicolumn{6}{|c|}{ Показники клітинного циклу (\%) } \\
\hline & & G0G1 & S & $\mathrm{G} 2+\mathrm{M}$ & IP & SUB-G0G1 & $\mathrm{BP}$ \\
\hline \multirow[b]{2}{*}{7} & $\begin{array}{l}\text { Інтактні } \\
\text { тварини }\end{array}$ & $83,61 \pm 2,14$ & $1,41 \pm 0,05$ & $14,98 \pm 2,14$ & $16,39 \pm 1,79$ & $2,59 \pm 0,30$ & $0,10 \pm 0,01$ \\
\hline & $\begin{array}{c}\text { Після неф- } \\
\text { ректомії }\end{array}$ & $82,69 \pm 1,09$ & $1,72 \pm 0,07^{*}$ & $15,59 \pm 1,08$ & $17,31 \pm 1,09$ & $3,28 \pm 0,36^{*}$ & $0,11 \pm 0,01$ \\
\hline \multirow{2}{*}{14} & $\begin{array}{l}\text { Інтактні } \\
\text { тварини } \\
\end{array}$ & $82,59 \pm 1,76$ & $1,38 \pm 0,05$ & $16,03 \pm 1,71$ & $17,41 \pm 1,52$ & $2,55 \pm 0,25$ & $0,09 \pm 0,01$ \\
\hline & $\begin{array}{l}\text { Після неф- } \\
\text { ректомії }\end{array}$ & $83,22 \pm 1,37$ & $1,51 \pm 0,05^{*}$ & $15,27 \pm 1,33$ & $16,78 \pm 1,37$ & $3,24 \pm 0,43 *$ & $0,10 \pm 0,01$ \\
\hline \multirow{2}{*}{21} & $\begin{array}{l}\text { Iнтактні } \\
\text { тварини } \\
\end{array}$ & $80,15 \pm 1,73$ & $1,38 \pm 0,04$ & $18,47 \pm 1,68$ & $19,85 \pm 1,63$ & $2,29 \pm 0,28$ & $0,07 \pm 0,01$ \\
\hline & \begin{tabular}{|c|} 
Після неф- \\
ректомії
\end{tabular} & $83,15 \pm 2,05$ & $1,40 \pm 0,02$ & $15,49 \pm 2,04$ & $16,85 \pm 2,05$ & $2,88 \pm 0,31 *$ & $0,09 \pm 0,01$ \\
\hline \multirow{2}{*}{30} & $\begin{array}{l}\text { Інтактні } \\
\text { тварини }\end{array}$ & $83,88 \pm 1,72$ & $1,51 \pm 0,04$ & $14,61 \pm 1,54$ & $16,12 \pm 1,58$ & $2,41 \pm 0,53$ & $0,10 \pm 0,005$ \\
\hline & $\begin{array}{l}\text { Після неф- } \\
\text { ректомії }\end{array}$ & $82,44 \pm 1,09$ & $1,23 \pm 0,03^{*}$ & $16,33 \pm 1,09$ & $17,56 \pm 1,09 *$ & $2,46 \pm 0,64$ & $0,08 \pm 0,004^{*}$ \\
\hline \multirow[b]{2}{*}{60} & $\begin{array}{l}\text { Iнтактні } \\
\text { тварини } \\
\end{array}$ & $85,03 \pm 1,69$ & $1,41 \pm 0,04$ & $13,56 \pm 1,48$ & $14,97 \pm 1,46$ & $2,43 \pm 0,29$ & $0,10 \pm 0,01$ \\
\hline & \begin{tabular}{|c|} 
Після неф- \\
ректомії
\end{tabular} & $84,64 \pm 1,14$ & $1,01 \pm 0,06^{*}$ & $14,35 \pm 1,12$ & $15,36 \pm 1,14$ & $2,46 \pm 0,58$ & $0,07 \pm 0,01^{*}$ \\
\hline \multirow{2}{*}{90} & $\begin{array}{l}\text { Інтактні } \\
\text { тварини } \\
\end{array}$ & $81,03 \pm 1,56$ & $1,45 \pm 0,04$ & $17,52 \pm 1,23$ & $18,97 \pm 1,12$ & $2,04 \pm 0,32$ & $0,08 \pm 0,01$ \\
\hline & \begin{tabular}{|c|} 
Після неф- \\
ректомії
\end{tabular} & $83,36 \pm 0,85^{*}$ & $0,81 \pm 0,11^{*}$ & $15,83 \pm 0,75^{*}$ & $16,64 \pm 0,85^{*}$ & $2,23 \pm 0,46$ & $0,05 \pm 0,01^{*}$ \\
\hline
\end{tabular}

Примітка:

* - статистично значущі відмінності ( $<0,05-0,01)$ за критерієм Манна-Уітні між відповідними показниками порівняно з контролем

тити різний ступінь збільшення клітин у цій фазі. Найбільше збільшення у 1,2 раза $(\mathrm{P}<0,05)$ зафіксовано на 7 добу. В подальшому темп зростання дещо сповільнився. На 14 добу кількість клітин була більшою у 1,1 раза $(\mathrm{P}<0,05)$. На 21 добу кількість клітин у фазі $\mathrm{S}$ статистично не відрізнялась від показника у інтактних тварин. Через 30 діб кількість клітин у фазі $\mathrm{S}$ була меншою у 1,2 раза (рис. 4), порівняно з показником у інтактних тварин, а через 60 діб (рис. 5) меншою у 1,4 раза $(\mathrm{P}<0,05)$. На 90 добу частка клітин кіркової речовини нирки у фазі S була меншою в 1,8 раза. Тобто після 30 доби синтетична діяльність клітин кіркової речовини зменшується.

У післясинтетичний період (фазі G2+M) - стадію безпосередньої підготовки до мітозу, коли у клітині накопичується енергія АТФ, що необхідна для кінетики внутрішньоклітинних процесів, кількість клітин кіркової речовини нирки у післяопераційний період у тварин основної групи (після нефректомії) не відрізнялась порівняно з інтактними тваринами. Лише на 90 добу цей показник був статистично значуще менший. За даними ряду дослідників [14], клітини, що затримались у фазі G2+M при зменшенні кількості клітин у фазі S, можуть бути гістологічним біомаркером прогресування хронічної ниркової хвороби.

Кількість клітин у G0 та G1 фазах порівняно 3 іншими фазами клітинного циклу була найбільшою $(81,32 \%$ - 84,68\%) протягом усього періоду спостереження.

За даними літератури [15], у період фази G0 клітини знаходяться в стані спокою і не діляться. У зрілому організмі паренхімні клітини нирок 
вступають у G0-фазу майже назавжди, i спонукати їх знову до поділу можуть лише особливі обставини. Очевидно, видалення контрлатеральної нирки і $є$ тою обставиною, що змушує клітину готуватися до синтетичної фази. У фазі G1 (пресинтетичний період) відбуваються такі біохімічні процеси: синтез макромолекулярних сполук, необхідних для побудови хромосом і ахроматинового апарату (ДНК, РНК, гістонів та інших білків), зростає кількість рибосом і мітохондрій, відбувається накопичення енергетичного матеріалу для здійснення структурних перебудов і складних рухів при розподілі. Клітина інтенсивно росте та може виконувати свою функцію [15].

Під час проведення оцінки показників фрагментації ДНК у клітинах кіркової речовини нирки серед нефректомованих щурів протягом 90 діб спостереження активації апоптозу в клітинах кіркової речовини нирки не відзначено у порівнянні 3 інтактними тваринами.

Проведені нами дослідження показали, що в тканині інтактних нирок щурів (контрольна група) рівень фрагментації ДНК становив від

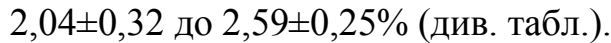

На 7-14 добу досліджуваного післяопераційного періоду виявлено статистично значиме підвищення рівня фрагментованої ДНК у тканині єдиної нирки, що підлягає гіпертрофії $(3,28 \pm 0,36$ та 3,24 $\pm 0,43$ відповідно).

Гіпертрофія єдиної нирки щурів після однобічної нефректомії супроводжується активацією апоптозу в тканині нирки, що виражається в збільшенні ДНК-фрагментації в нирковій тканині однієї нирки експериментальних тварин. Пік цієї активації спостерігався на 7 добу після нефректомiï.

Висновки. 1. Отримані нами показники дозволяють характеризувати клітинний цикл клітин кіркової речовини єдиної нирки і вказують на підвищення активності проліферації та оновлення в найближчому післяопераційному періоді після нефректомії, що пояснює зростання маси та об'єму нирки. 2. Гіпертрофія єдиної нирки щурів після однобічної нефректомії супроводжується активацією апоптозу в тканині нирки, що виявляється у збільшенні ДНК-фрагментації в нирковій тканині однієї нирки експериментальних тварин. Пік цієї активації спостерігався на 7 добу після нефректомії. Це вказує на активацію апоптозу в умовах посиленої проліферації.

Перспективи подальших досліджень. У подальших дослідженнях доцільно порівняти динаміку показників клітинного циклу та фрагментації ДНК клітин кіркової речовини єдиної нирки, що залишилася після нефректомії, у статевозрілих і статевонезрілих щурів.

\section{Список використаної літератури}

1. Effect of unilateral nephrectomy on renal function of diabetic rats / G.S. Lopes, C.C. Lemos, C.A. MandarimDe-Lacerda, R. Bregman // Histol. Histopatol. - 2004. - Vol. 19, № 4. - P. 1085-1088. 2. Renal function and adaptive changes in patients after radical or partial nephrectomy / A.A. Antoniewicz, S. Poletajew, A. Borówka [et al.] // Int. Urol. Nephrol. - 2012. - Vol. 44, № 3. - P. 745-751. 3. Compensatory Growth of Congenital Solitary Kidneys in Pigs Reflects Increased Nephron Numbers rather Than Hypertrophy / S.H. van Vuuren, C.M. Sol, R. Broekhuizen [et al.] // PLoS One. - 2012. - Vol. 7, № 11. - P. 49735. 4. Little M.H. Regrow or repair: potential regenerative therapies for the kidney / M.H. Little // J. Am. Soc. Nephrol. - 2006. - Vol. 17, № 9. - P. 2390-2401. 5. Rosenblum N.D. Developmental biology of the human kidney / N.D. Rosenblum // Seminars in fetal \& neonatal medicine. - 2008. - Vol. 13. № 3. - P. 125-132. 6. Epithelial cell cycle arrest in G2/M mediates kidney fibrosis after injury / L. Yang, T.Y. Besschetnova, C.R. Brooks [et al.] // Nat Med. 2010. - Vol. 16, № 5. - P. 535-543. 7. Состояние компенсаторных процессов в единственной почке и уровень перекисного окисления в плазме крови в эксперименте / Т.П. Сатаева, К.Л. Лазарев, А.Н. Захарова, В.А. Житова // Таврический медико-биолог. вестн. - 2009. - Т. 12, № 3 (47). - С. 110-113. 8. Compensatory hypertrophy after partial and radical nephrectomy in adults / T. Takagi, M.C. Mir, N. Sharma [et al.] // J. Urol. - 2014. - Vol. 192, № 6. - P. 1612-1618. 9. Heine W. Tageszeitliche Phytmen der zellproliferation in der kompensatorisch regenerierenden Niere nach unilateraler nephrectomie / W. Heine, E. Stocker, H. Heine // Virchow's Arch. - 2002. - Bd. 9, № 1. - S. 75-96. 10. Fujigaki Y. Different modes of renal proximal tubule regeneration in health and disease / Y. Fujigaki // World J. Nephrol. - 2012. - Vol. 1, № 4. - P. 92-99. 11. Yoshida M. Regeneration of injured renal tubules /M. Yoshida, S. Honma // J. Pharmacol. Sci. - 2014. - Vol. 124, № 2. - P. 117-122. 12. Podocyte mitosis - a catastrophe / L. Lasagni, E. Lazzeri, S.J. Shankland [et al.] // Curr. Mol. Med. - 2013. - Vol. 13, № 1. - P. 13-23. 13. Darzynkiewicz Z. Analysis of Cellular DNA Content by Flow and Laser Scanning Cytometry /Z. Darzynkiewicz, H.D. Halicka, H. Zhao // Adv. Exp. Med. Biol. - 2010. - Vol. 676. - P. 137-147. 14. Bonventre J.V. Primary proximal tubule injury leads to epithelial cell cycle arrest, fibrosis, vascular rarefaction, and glomerulosclerosis / J.V. Bonventre // 
Kidney Int. Suppl. - 2014. - Vol. 4, № 1. - P. 39-44. 15. A high ratio of G1 to G0 phase cells and an accumulation of $G 1$ phase cells before $S$ phase progression after injurious stimuli in the proximal tubule $/ T$. Iwakura, Y. Fujigaki, T. Fujikura [et al.] // Physiol. Rep. -2014. - Vol. 2, № 10. - P. 12173.

\section{ПОКАЗАТЕЛИ КЛЕТОЧНОГО ЦИКЛА КЛЕ- ТОК КОРЫ ЕДИНСТВЕННОЙ ПОЧКИ ПО- СЛЕ КОНТРЛАТЕРАЛЬНОЙ НЕФРЭКТО- МИИ}

Резюме. В эксперименте на крысах с помощью метода проточной ДНК-цитометрии изучена динамика показателей клеточного цикла и фрагментации ДНК клеток коры единственной почки, оставшейся после нефрэктомии у крыс. Установлено повышение активности пролиферации и обновления в ближайшем послеоперационном периоде после нефрэктомии, что объясняет рост массы и объема почки. Гипертрофия единственной почки крыс после односторонней нефрэктомии сопровождается активацией апоптоза в ткани почки, выражающееся в увеличении ДНК-фрагментации в почечной ткани одной почки у экспериментальных животных. Пик этой активации наблюдался на 7 сутки после нефрэктомии. Это указывает на активацию апоптоза в условиях усиленной пролиферации.

Ключевые слова: единственная почка, клеточный цикл, ДНК-цитометрия.

\section{INDICATORS OF THE CELLULAR CYCLE OF THE RENAL CORTEX CELLS IN THE SINGLE KIDNEY AFTER CONTRALATERAL NEPHRECTOMY}

Abstract. In the experiment on rats by means of flow DNA-cytometry the dynamics of the cell cycle dynamics and DNA fragmentation of the renal cortex cells of the only kidney remaining after nephrectomy in rats was studied. Increase of proliferation activity and renewal in the immediate postoperative period after nephrectomy were found, which explains the increase in the mass and volume of the kidney. Kidney hypertrophy after unilateral nephrectomy in rats is accompanied by activation of apoptosis in the kidney tissue, resulting in increase of DNA fragmentation in the renal tissue of one kidney in experimental animals. The peak of this activation was observed on the 7th day after nephrectomy. It is indicative of apoptosis activation under conditions of intensified proliferation.

Key words: single kidney, cellular cycle, DNAcytometry.

M.I. Pyrogov Memorial Vinnytsia National Medical University (Vinnytsia)

Надійшла 22.04.2016 p. Рецензент - проф. Зайцев В.І. (Чернівці) 